\title{
- Invited Review - Insect meal as a feed ingredient for poultry
}

\author{
Usman Elahi ${ }^{1,2}$, Chang-chun $\mathrm{Xu}^{1}$, Jing Wang ${ }^{1}$, Jing Lin ${ }^{1}$, Shu-geng $\mathrm{Wu}^{1}$, \\ Hai-jun Zhang ${ }^{1}{ }^{1 *}$, and Guang-hai Qi ${ }^{1}{ }^{* *}$
}

\author{
* Corresponding Authors: \\ Hai-jun Zhang \\ Tel: +86-10-8210-6097 \\ E-mail: zhanghaijun@caas.cn \\ Guang-hai Qi \\ Tel: +86-10-8210-7317 \\ E-mail: qiguanghai@caas.cn
}

${ }^{1}$ Key Laboratory of Feed Biotechnology, Ministry of Agriculture and Rural Affairs,

National Engineering Research Center of Biological Feed, Feed Research Institute, Chinese Academy of Agricultural Sciences, Beijing 100081, China

${ }^{2}$ Institute of Animal and Dairy Sciences, Faculty of Animal Husbandry, University of Agriculture, Faisalabad 38000, Pakistan

\section{ORCID}

Usman Elahi

https://orcid.org/0000-0003-0033-4337 Chang-chun Xu

https://orcid.org/0000-0002-6291-3935 Jing Wang

https://orcid.org/0000-0003-3694-6001 Jing Lin

https://orcid.org/0000-0001-6906-2873

Shu-geng Wu

https://orcid.org/0000-0002-2797-8266 Hai-jun Zhang

https://orcid.org/0000-0002-9149-600X

Guang-hai Qi

https://orcid.org/0000-0002-1540-9525

Submitted Sept 23, 2021; Revised Oct 7, 2021; Accepted Nov 16, 2021

Parts of this review were presented at Animal Bioscience Forum 2021 on Animal Biosciences to Improve Animal Health and Production: Insect proteins for animals - current status, potentials and challenges (September 28-29, 2021), which was supported by Pathway Intermediates (http://www.pathwayintermediates.com).

\begin{abstract}
Shortage of protein feed resources is the major challenge to the world farm animal industry. Insects are known as an alternative protein source for poultry. A wide range of insects are available for use in poultry diets. Insect larvae thrive in manure, and organic waste, and produce antimicrobial peptides to protect themselves from microbial infections, and additionally these peptides might also be functional in poultry feed. The feed containing antimicrobial peptides can improve the growth performance, nutrient digestibility, intestinal health, and immune function in poultry. Insect meal contains a higher amount of essential amino acids compared to conventional feedstuffs. Black soldier fly, mealworm, housefly, cricket/Grasshopper/Locust (Orthoptera), silkworm, and earthworm are the commonly used insect meals in broiler and laying hen diets. This paper summarizes the nutrient profiles of the insect meals and reviews their efficacy when included in poultry diets. Due to the differences in insect meal products, and breeds of poultry, inconsistent results were noticed among studies. The main challenge for proper utilization, and the promising prospect of insect meal in poultry diet are also addressed in the paper. To fully exploit insect meal as an alternative protein resource, and exert their functional effects, modes of action need to be understood. With the emergence of more accurate and reliable studies, insect meals will undoubtedly play more important role in poultry feed industry.
\end{abstract}

Keywords: Broiler; Growth Performance; Immune Function; Insect Meal; Laying Hen; Meat Quality

\section{INTRODUCTION}

Fish meal and soybean meal are the conventional protein sources in poultry feed. In poultry production, feed cost is approximately $60 \%$ to $80 \%$ of the total cost. A possible solution to reduce poultry feed costs is finding available, efficient, and inexpensive alternative feed sources. Insects are natural foods for poultry. Chickens can be found picking worms, and larvae from the grass, soil, and litter where they walk.

Insects are capable of consuming animal manure, and food wastes, and reducing pollution, and providing protein (larvae), and fertilizer (frass). Insects convert waste into proteins, and reduce total nitrogen excretion, odors, and methane emission, thus reduce up to $80 \%$ of waste mass [1-3].

The use of insects in poultry feed is a potential solution to improve the sustainability of poultry diets. A wide range of insects are available for use in poultry diets [4]. Insect meal contains a greater amount of essential amino acids compared to conventional feedstuffs [4]. The insects can be used as a live (fresh), dried, and paste form for poultry diets [5,6]. A dried insect is considered suitable for poultry diet because the water content in fresh or live insect stimulates the degradation, antimicrobial activity, and Millard reaction [6,7]. 
The exoskeleton of insects mainly consists of chitin, which improves the immune system of chicken [4]; however, chicken cannot synthesize the chitin [8]. Chitin and chitin derivatives can stimulate the innate immune cells [9]. Chitin contains about $5 \%$ nitrogen $[10,11]$. Broiler chickens fed the diet containing mealworm meal (MWM) have better disease resistance, and immune response due to prebiotic effect of chitin [12]. Chitin in diet also halts the growth of Escherichia coli, Salmonella, and Salmonella enterica serovar Typhimurium in broiler chickens $[13,14]$. Furthermore, hypolipidaemic and hypocholesterolaemic properties of chitin produce leaner meat by decreasing body fat in broiler chickens [8]. However, insects are recognized as disease carriers and there is a threat that insect borne diseases could transfer to poultry, and humans [15]. Black soldier fly (BSF; Hermetia illucens) does not carry any disease-causing agent; however, housefly (HF; Musca domestica) is a carrier of Entomophthora spp. fungus, house cricket (Acheta domesticus) is a carrier of Metarhizium sp. fungus and cricket paralysis virus, and mealworm (Tenebrio molitor) is a carrier of Beauveria bassiana fungus [16]. Insect larvae produce antimicrobial peptides to protect themselves from microbial infections as well as these peptides could also be functional in poultry $[3,17]$. Moreover, proper processing of insects could reduce the chemical risks and makes it gluten free $[18,19]$. Insects also contain antimicrobial peptides that are active against microbial resistant, bacteria, viruses, fungi and parasites as well as being used in medicines for wounds, infections, cancer, flatulence, phlegm, spasms and anticoagulation [17]. Antimicrobial peptide P5 is antibiotic alternative which acts as a growth promoter [20]. In addition, antimicrobial peptides improve the growth performance, nutrient digestibility, gut health and immune functioning [21]. Furthermore, the dark color of insect cuticle is due to the bioactive phenolic compound melanin having antibacterial and antifungal activity as well as prevents and treats hepatic diseases, stress and tumors [22-24]. In addition, insects are enriched in fatty acids that have antimicrobial properties. One of which, Lauric acid, is known for antibacterial and antiviral activity [25].

Insect meal in poultry diets increases the palatability for chickens and chickens fed on insect meal are highly preferable by consumers [4]. Insect meal enhances immune system and reduces antibiotic use thus, promoting animal health [8]. Moreover, feeding grasshoppers to chickens improved the shelf life of the meat [26]. Using insect meal in diet reduces feed cost, and enhances the performance and health of broiler chickens [27]. Thus, insect meal is an acceptable, inexpensive, and preferable source of protein for poultry.

\section{BLACK SOLDIER FLY (Hermetia illucens) MEAL}

Black soldier fly meal (BSFM) is a good source of protein, and energy, enriched with essential, and nonessential amino acids, saturated, monounsaturated, and polyunsaturated fatty acids (PUFA), vitamins, and minerals $[10,28,29]$. The concentration of crude protein (CP) in BSFM ranged from $35 \%$ to $61 \%$. Reported values for CP are, $34.97 \%$ [10], 36.94\% [30], 36.9\% [31], 40\% [32], 42.6\% CP [33], 43.9\% [34], 55.3\% [11], 55.3\% [35], 56.1\% [36], and 60.8\% [37-40]. Black soldier fly contains higher concentrations of lauric acid and palmitic acid [41]. The concentration of crude fat in BSFM ranged from $7 \%$ to $42 \%$. Reported values for crude fat are, $6.84 \%$ [36], 14.1\% [37-40], 18\% [11,35], 29.4\% [34], 32.5\% [32], $34.3 \%$ [31], 35.49\% [10], 36.9\% [33], and 42.27\% [30]. Methionine content in BSFM ranged from $0.08 \%$ to $0.90 \%$. Reported values for methionine are, $0.08 \%$ [39], $0.50 \%$ [10], $0.60 \%$ [30], $0.64 \%$ [11], $0.75 \%$ [37,38,40], $0.80 \%$ [34], and $0.90 \%[31,36]$, however, methionine + cysteine is $1.30 \%$ [36]. The concentration of lysine ranged from $0.34 \%$ to $3.30 \%$, and threonine ranged from $0.22 \%$ to $2.26 \%$. Reported values for lysine are, $0.34 \%$ [39], 2.10\% [10,11], 2.15\% [30], 2.23\% [31], 2.81\% [34], 3.22\% [36], and 3.29\% [37, 38], 3.30\% [37, $38,40]$, and, reported values of threonine are $0.22 \%$ [39], $1.52 \%$ [31], $1.63 \%$ [34], 1.72\% [11], 2.17\% [37,38,40], and $2.26 \%$ [36]. And reported concentration of valine in BSFM is $0.33 \%$ [39], $2.20 \%$ [31], $2.50 \%$ [34], $2.72 \%$ [11], 3.25\% $[37,38], 3.26 \%[37,38,40]$, and $3.38 \%$ [36]. Black soldier fly larvae contain 3 to 10 times higher calcium and magnesium content than other insects [42]. The concentrations of calcium and phosphorus in BSFM are ranged from $1.21 \%$ to $4.39 \%$, and $0.74 \%$ to $0.95 \%$ respectively. Reported values for calcium are $1.21 \%$ [36], 2.46\% [30], 4.39\% [10], and for phosphorus are $0.74 \%$ [30], 0.83\% [10], and 0.95\% [36].

In addition, BSF larvae reduces manure mass by $50 \%$, and total nitrogen concentration by $62 \%$ [43]. The rapid consumption of the substrate reduces odors and therefore presumably methane formation and off-gassing. Moreover, rearing BSF larvae on animal manure could help to reduce feed cost, HF population (by repelling ovi-position), pathogenicity (by producing certain enzymes) and odor $[3,44,45]$.

Considerable studies showed that BSFM is the superior insect protein to improve growth performance, carcass composition, and meat quality in broiler chickens. Diet containing 2.6\% BSFM with extended amino acids supply in the diet of Ross 308 broiler chickens improved the growth performance and nitrogen balance in starter phase [37]. Cobb broiler chickens fed diet containing 5\% BSFM had improved feed efficiency, and $7.5 \%$ BSFM increased the thigh weight and reduced meat $\mathrm{pH}$, and 10\% BSFM still resulted in better growth [46]. Diet containing 20\% BSFM fed to Ross 308 male broiler chickens improved the meat quality by increasing concentrations of lauric acid, myristic acid, and eicosapentaenoic fatty acid; however, partly reduced the total PUFA [32]. In another 
study, diet containing 5\% BSFM fed to Ross 708 male broiler chickens improved the cecal microbiota population and preservation, and increased villi mucin; however, chickens fed on 15\% BSFM had reduced cecal microbiota population and preservation [35]. Diet containing 5\% BSFM fed to broiler chickens reduced the abdominal fat percentage; $10 \%$ BSFM increased the carcass weight and breast percentage, and $15 \%$ BSFM increased the body weight, abdominal fat percentage, meat redness, meat protein percentage, breast meat monounsaturated fatty acids (MUFA), and reduced breast meat PUFA [47]. Diet containing 5\% or 10\% BSFM fed to Ross 308 broiler chickens led to improved growth performance; however, 15\% BSFM in diet decreased the feed efficiency, and resulted in the increase of crypt depth and reduction of villus height, and villus height crypt depth ratio [48]. Cobb 500 broiler chickens fed on the diet containing 2\% BSFM had decreased abdominal fat weight; diet containing $6 \%$ BSFM increased the protein digestibility and reduced the excreta Enterobacteriaceae count; 8\% BSFM had better growth performance, and 10\% BSFM increased drip loss, and decreased the gizzard weight [49]. Indigenous Ardennaise chickens fed on $8 \%$ fresh BSF exhibited higher body weight [41]. Diet containing (3\% or 6\%) BSFM fed to Ross 308 broiler chickens increased the breast meat yield and feed efficiency; however, reduced the weight gain [20]. BSFM at the dosage of $3 \%$ exhibited immunomodulatory effects, as evidenced by the increase of the CD3+CD4+ T lymphocytes, cell proliferation, lysozyme, survivability against Salmonella Gallinarum, and decrease of the bacteria count in the tissues of liver, spleen, bursa, and cecum [50].

The effects of BSFM on broiler chicken were affected by the dietary ratio between methionine and cysteine. Ross 308 male broiler chickens fed on the diet containing 23\%/21\% BSFM (starter/grower phase) with 50:50 methionine cysteine ratio improved feed efficiency, increased net protein utilization and body crude fat deposition; diet with 40:60 methionine cysteine ratio reduced the growth performance, methionine precaecal digestibility, and net protein utilization; diet containing 60:40 methionine cysteine ratio increased amino acids (methionine, threonine, arginine, leucine and valine) precaecal digestibility; however, diet with 55:45 methionine cysteine ratio only increased the cysteine precaecal digestibility [39].

Black soldier fly meal can be used to replace fish meal and/or soybean meal or even soybean oil in broiler diet. Fish meal was successfully replaced by BSFM up to $15 \%$ in the diet of domestic chickens [51]. Cobb 500 broiler chickens fed on the diet containing $33 \%$ BSFM ( $4 \%$ in diet) as a replacement of fish meal resulted in increased dressing percentage and protein deposition in meat [52]. Ross 308 broiler chickens fed on the diet containing $50 \%$ or $100 \%$ BSFM with an ideal amino acid ratio as a replacement of soybean meal improved the growth performance, while diet containing 100\% BSFM with deficient methionine level reduced the feed intake, protein and energy conversion ratio [40]. Cobb 500 broiler chickens fed diet containing 5\% BSFM as replacement of soybean meal and fish meal, had better growth performance, and higher gizzard weight; and 10\% BSFM increased the breast weight, and overall acceptability of cooked pectoral muscle; while 15\% BSFM reduced the aroma, and taste of cooked pectoral muscle, total feed cost, and increased gross profit margin [34]. Ross 308 broiler chickens fed on the diet containing 75\%/50\% BSFM (75\% for starter phase and 50\% for grower phase), or $50 \%$ or $100 \%$ BSFM with extended amino acids supply as replacement of soybean meal improved growth performance and CP deposition; further, $50 \%$ BSFM and 100\% BSFM with extended amino acids supply, yielded superior protein quality model parameter and net protein utilization [38]. BSFM was successfully included at $15 \%$ in the diet of Cobb 500 broiler chickens [53] and soybean oil was successfully replaced with $100 \%$ BSF fat for Ross 308 male broiler chickens [54]. Diet containing $100 \%$ BSFM as a replacement of soybean oil exhibited increased proportion of saturated fatty acids and reduced proportion of PUFAs of breast meat, and did not affect the growth performance, hematological parameters, carcass, and meat quality [55]. Black soldier fly fat could be used to replace $50 \%$ of soybean oil and reduced cholesterol in the breast meat in Ross 708 broiler chickens; while 100\% BSF fat increased the total saturated fatty acids and reduced the MUFA, PUFA in breast and leg meat [56]. Ross 308 male broiler chickens fed diet containing $2.5 \%$ partially defatted BSFM resulted in increased digestibility of crude fat, and apparent metabolizable energy compared to chickens fed $2.5 \%$ full defatted BSFM [11]. BSFM included in the diet of Ross 708 broilers at $25 \%$ resulted in increased coefficient of total track apparent digestibility for ether extract compared to the chickens fed on 25\% MWM diet [31]. BSFM could be used at $7.8 \%$ in combination with $5.2 \%$ alfalfa meal as a replacement of soybean cake to improve growth performance, carcass composition and meat redness in Hubbard S757 broilers [57].

There were few studies regarding the effects of BSFM in laying hens, and variable results were observed. Hy-Line Brown laying hens fed on 3\% BSFM improved the growth performance, apparent digestibility of $\mathrm{CP}$ and crude fat, immunoglobulin A and glutathione peroxidase [10]. Laying hens (Julia) fed on the diet containing 10\% BSFM increased the egg weight, albumin weight, egg shell thickness, albumin height, plasma calcium; furthermore, diet containing $10 \%$ BSF larvae meal significantly improved the egg yolk color score [28]. Lohman brown classic laying hens fed on diet containing 15\% defatted BSFM and fat improved egg weight, egg mass, nitrogen, and energy metabolizability [58]. Xuefeng 
black-bone laying hens fed on 3\% BSFM diet improved the egg weight, Haugh unit, egg shell weight, yolk C14:00, C17:00, C20:2 fatty acids, yolk amino acids (glutamic acid, methionine, phenylalanine and leucine), plasma total superoxide dismutase, and plasma avian influenza virus antibody, and decreased the egg shell thickness, and plasma interleukin-2; still, hens fed on 5\% BSFM diet improved egg production, and feed efficiency, and decreased plasma malondialdehyde [30]. Diet containing 7.5\% BSFM fed to Shaver white leghorn hens increased the feed intake, body weight (27 week), yolk color score, and shell thickness; however, 5\% BSFM in diet increased body weight (23 week) and shank breaking strength but reduced the hen day egg production, egg weight, egg mass, and feed intake [36]. Lohman Brown Classic laying hens fed on the diet containing $17 \%$ BSFM to fully replace soybean meal resulted in poor growth, and production percentage, decreased blood lipids, blood chloride, and blood creatine; however, increased percentage of small, medium, and extralarge size eggs, blood globulin and blood calcium [59]. Diet containing $24 \%$ BSFM as replacement of soybean cake fed to Lohmann selected leghorn classic laying hens exhibited increases of the fecal dry matter [60].

\section{MEALWORM (Tenebrio molitor) MEAL}

Mealworms are the brown worm-like larvae of the darkling beetles. Mealworms can be found throughout most of the world where they prefer warm, dark, and damp places like under decaying logs and leaves. Mealworms are designed for burrowing and eating and will feast upon the grains, vegetation, spoiled food, and many other types of fresh or decaying organic matter.

The concentration of CP in MWM ranged from $27 \%$ to $54 \%$, and fat ranged from $4 \%$ to $34 \%$. Reported values for CP concentration in MWM are 46.44\% [61], 51.93\% [12], $52.89 \%$ [6], 53.83\% [62], 47\% [63], 53\% [64], 27.26\% [65], $27.15 \%$ for super MWM [65], 45.83\% [66], and 52.4\% [31]. Reported values for crude fat in MWM are 21.27\% [12], 30.05\% [6], 28\% [31], 28.03\% [62], 29.6\% [63], 3.6\% [64], 11.50\% [65], 8.70\% for super MWM [65], and 34.2\% [66]. Broiler chickens fed on the diet containing MWM have better disease resistance and immune responses due to prebiotic effect of chitin [12].

Arbor Acres broiler chickens fed on diet containing 2.5\% MWM improved the weight gain (1 to $10 \mathrm{~d}$ ) and reduced the albumen globulin ratio; however, 5\% MWM reduced the albumen globulin ratio and intestinal Escherichia coli count [62]. Diet containing 4\% MWM fed to Ross 308 male broiler chickens improved the body weight, average daily gain, and feed conversion ratio (FCR) in the starter phase [6]. Mealworm meal in diet of Ross 308 broiler chickens at the rate of $0.3 \%$ increased the weight gain, feed intake, blood total protein, blood total cholesterol, serum interleukin-2 and serum tumor necrosis factor a [63] and increased the cecal a-glucosidase [67]. Higher level of MWM (10\% to 15\%) in the diet of Ross 708 broiler chickens resulted in reduced firmicutes Bacteroidetes ratio and mucin synthesis [68]. Label Hubbard hybrid free range chickens fed on 7.5\% MWM as a replacement of corn gluten meal in diet increased the oleic acid percentage and $\alpha$-linolenic acid percentage, and reduced the atherogenicity and thrombogenicity indexes of breast meat [69]. Shaver brown male broiler chickens fed on diet containing MWM exhibited higher amount of volatile fatty acids of cecal content [70]. Ross 708 male broiler chickens fed on the diet containing 15\% MWM as a replacement of soybean meal, corn gluten meal and soybean oil resulted in increased body weight (12 d), feed intake, FCR ( 25 to $53 \mathrm{~d}$ ), and crypt depth, and reduced villus height, and villus height crypt depth ratio; however, body weight at 25 d was increased by $10 \%$ MWM and body weight at $53 \mathrm{~d}$ was increased by $5 \%$ MWM [71]. Diet containing $8 \%$ MWM fed to Ross 308 broiler chickens resulted in increased body weight, meat tenderness, and juiciness; however, decreased feed intake, and FCR [64]. Ross 708 female broiler chickens fed on diet containing 15\% full fat MWM as a replacement of soybean meal, corn gluten meal and soybean oil exhibited increased body weight (12 d), and weight gain at $12 \mathrm{~d}$, feed intake ( 1 to $12 \mathrm{~d}$ ), thigh weight and abdominal fat weight; however, $5 \%$ MWM increased the body weight at $40 \mathrm{~d}$, feed intake (12 to $25 \mathrm{~d}$ ), and carcass weight [72]. In addition, $10 \%$ MWM increased the abdominal fat percentage and red blood cells; however, reduced the blood albumin and blood gamma glutamyl transferase [72]. Chickens fed a 3\% MWM in diet exhibited increased weight gain, dressing percentage, feed cost, total expenses, gross return, and net profit [66]. Ross 308 male broiler chickens infected with Salmonella enteritidis and Escherichia coli, fed on the diet containing 0.4\% MWM resulted in increased feed intake, serum IgA, and reduced mortality and cecal Escherichia coli; however, $0.4 \%$ super MWM increased the body weight, weight gain, serum immunoglobulin G, and reduced FCR, bursa of fabricius percentage, cecal Salmonella spp. [65].

Corn gluten meal in diets of female label Hubbard hybrid free-range chickens, was successfully replaced by 7.5\% MWM without any effect [73]. Diet containing 29.65\% MWM as a replacement of soybean meal with hulls in the diet of Shaver brown broiler chickens improved the FCR, ileal digestibility, and spleen weight [74]. Shaver brown male broiler chickens fed on diet containing 29.65\% MWM showed improved FCR, protein efficiency ratio (PER), European efficiency factor, aspartate aminotransferase and alanine aminotransferase; however, reduced feed intake (46 to $62 \mathrm{~d}$ ), albumin globulin ratio and uric acid [12]. Diet containing 25\% MWM fed to the Ross 708 broiler chickens increased apparent ileal digestibility 
coefficient for isoleucine, lysine, methionine, phenylalanine, valine, alanine, aspartic acid, glycine, glutamic acid, and tyrosine compared to the chickens fed on the diet containing $25 \%$ BSFM diet [31]. Mealworm meal can also regulate the meat quality of poultry. The MWM sloth at $1 \%$ dosage reduced meat color redness, meat color yellowness, meat palmitic acid, palmitoleic acid, linoleic acid and saturated fatty acids, and increased meat oleic acid and unsaturated fatty acids [75]. Broiler chickens fed on the diet containing 1\% MWM increased the body weight, weight gain; in addition, diet containing $2 \%$ MWM increased the carcass yield, slaughter weight, dressed weight, eviscerated weight, and reduced the abdominal fat weight; however, diet containing 10\% MWM decreased the feed efficiency [76].

\section{HOUSEFLY (Musca domestica) MEAL}

The HF can be found in all countries and in any climates. It is commonly associated with animal feces and can be found feeding on animal manure and food wastes. The concentration of CP in HF meal (HFM) ranged from $40 \%$ to $64 \%$, and crude fat in HFM ranged from $2.5 \%$ to $28 \%$. HFM contains about $53.3 \% \mathrm{CP}$ [77], 54.36\% CP and $16.90 \%$ crude fat [78], $55.1 \% \mathrm{CP}$ and $20.7 \%$ crude fat [79], 55.6\% CP and $27.9 \%$ crude fat [80], 59.48\% CP and $6.66 \%$ crude fat [81], 63.99\% CP and $24.31 \%$ crude fat [82], 61.25\% CP [83], 44.44\% CP and $9.76 \%$ crude fat [84], $48.4 \% \mathrm{CP}$ and $20 \%$ crude fat [85], 62.98\% CP and 5.58\% crude fat [86], 40.12\% CP and 6.88\% crude fat [87], 50\% CP and $2.7 \%$ crude fat [64]. The older HF larvae contain less $\mathrm{CP}$ and more lipids than young HF larvae $[88,89]$. The amino acid profile of HFM is comparable to fish meal, most limiting amino acids, lysine, and methionine are in higher concentration. Insect processing method could also influence the nutritional profile of the insect meal. Sun drying reduces $\mathrm{CP}$ and increases lipids compared to oven drying [89].

Housefly meal can be used as a substitute for fish meal or soybean meal, and HFM can improve the production performance $[84,86,90-92]$ and meat quality of broilers [80, 93,94] at different concentrations. Diet containing 20\% HFM as a replacement of fish meal fed to Anak broiler chickens increased the body weight, feed intake, FCR and gizzard percentage; however, diet containing 40\% HFM increased weight gain, dressing percentage and inguinal fat percentage [84]. Ross 308 male broiler chickens fed 4\% HFM diet had better growth performance, while dietary $8 \%$ HFM addition harmed the growth of starter [86]. Broiler chickens fed on the $60 \%$ HFM as replacement of soybean meal in diet, improved the body weight, FCR, dressing percentage, apparent metabolizable energy, nutrient digestibility and reduced the feed intake [90]. Yellow dwarf male chickens fed on $4.44 \%$ HFM as a replacement of fish meal in diet improved the weight gain and feed intake [91]. Diet containing 10\% HFM fed to Ross 308 broiler chickens exhibited improved body weight ( 28 to $35 \mathrm{~d}$ ), feed intake ( 28 to $35 \mathrm{~d}$ ), weigh gain, FCR, European production efficiency factor (EPEF) and PER; however, diet containing 50\% HFM reduced body weight ( 21 to $35 \mathrm{~d}$ ), feed intake ( 21 to $35 \mathrm{~d}$ ), weight gain, FCR, EPEF, and PER [92]. However, the HFM at the rate of $20 \%, 40 \%$, and $60 \%$ was successfully replaced with fish meal in the diet of Ross 308 male broiler chickens without any significant effect [77]. Cobb 500 broiler chickens fed on the diet containing 5\%q HFM for starter phase and, 4\% HFM for grower and finisher phase, improved the body weight, weight gain, feed intake, FCR, meat flavor, meat aroma, meat desirability; moreover, 10\% HFM increased the meat juiciness and flavor, and 20\% HFM increased the meat tenderness and flavor [80]. Ross 308 broiler chickens fed on 10\% HFM increased the body weight, carcass weight, breast muscle yield, juiciness, water holding capacity, and reduced the thawing loss and cooking loss [93]. Housefly live larvae was reported to have the potential to improve the reproductivity of free range chicken, as evidenced by the increased clutch size and hatchability [95]. Furthermore, 50\% replacement of fish meal with HFM improved the hen day egg production in Isa brown and Nera black layer hens [96]. Table 1 summarizes the representative data of housefly meal application in broilers.

Everything has pros and cons. There are opinions that using maggot meal in poultry diets can enhance the risk of disease transmission. Houseflies are recognized as a carrier of diseases; they carry disease causing agents on their legs and hairs that cover their bodies. But the maggot itself doesn't contain any disease-causing agent because maggot therapy has been used for decades for the treatment of septic injuries.

\section{CRICKET/GRASSHOPPER/LOCUST (Orthoptera) MEAL}

Cricket/Grasshopper/Locust (Orthoptera) meal (OTM) is a rich source of protein, amino acids, fatty acids, minerals, and vitamins $[97,98]$. The concentration of CP ranged from $48 \%$ to $65 \%$ and crude fat ranged from $3 \%$ to $21 \%$. Short horned grasshopper (Oxya hyla hyla) contains about $64.67 \%$ CP, $2.58 \%$ crude fat [97], reared African grasshopper (Acanthacris ruficornis) contains about $50.5 \% \mathrm{CP}$ and $18.8 \%$ crude fat, desert locust (Schistocerca gregaria) contains about 50.9\% CP and 20.5\% crude fat, and wild edible grasshopper (Ruspolia nitidual) contains about 52\% CP and $21.4 \%$ crude fat [99]. However, (Ornithacris cavroisi) grasshopper contains about $47.73 \% \mathrm{CP}$ and $12.23 \%$ crude fat [100]. Chinese grasshopper (Acrida cinerea) contains about $65.4 \% \mathrm{CP}$ and $8.3 \%$ crude fat [98]. Grasshopper contains about $52.50 \% \mathrm{CP}$ and $27.1 \%$ crude fat [101].

Arbor Acres broiler chickens fed on the diet containing 
Table 1. Application of housefly meal with different addition levels in broilers

\begin{tabular}{|c|c|c|c|c|c|}
\hline References & $\begin{array}{l}\text { Inclusion } \\
\text { level (\%) }\end{array}$ & $\begin{array}{l}\text { Replacement/ } \\
\text { Alternative of }\end{array}$ & Percentage in diet & Poultry type & Results \\
\hline [82] & $\begin{array}{c}0 \\
5 \\
10 \\
15 \\
20\end{array}$ & Soybean meal & $32 \%$ & $\begin{array}{l}\text { Ross male commercial } \\
\text { broiler chickens }\end{array}$ & $\begin{array}{l}5 \% \text { HFM improved dressing percentage } \\
(p \leq 0.05) \\
10 \% \text { HFM improved breast muscle yield } \\
(p \leq 0.05) \\
15 \% \text { HFM improved live weight }(p \leq 0.05), F C R \\
\text { ( } p \leq 0.05) \text { and thigh muscle yield }(p \leq 0.05) \\
\text { Muscle amino acids concentrations }(p \leq 0.05)\end{array}$ \\
\hline [96] & $\begin{array}{c}0 \\
25 \\
75 \\
100\end{array}$ & Fish meal & $25 \%$ & $\begin{array}{l}\text { Isa brown and Nera black } \\
\text { layer hens }\end{array}$ & $\begin{array}{l}50 \% \text { HFM improved the hen day egg produc- } \\
\text { tion }(p \leq 0.05) \text { and reduced the shell thickness } \\
(p \leq 0.05) \\
100 \% \text { HFM reduced the shell weight }(p \leq 0.05)\end{array}$ \\
\hline [79] & $\begin{array}{c}0 \\
25 \\
50 \\
75 \\
100\end{array}$ & Fish meal & $4 \%$ & Anak 3,000 broiler chicken & $\begin{array}{l}50 \% \text { HFM reduced the Weight gain }(p \leq 0.05) \\
\text { and Nitrogen retention }(p \leq 0.05) \\
75 \% \text { HFM reduced the Protein efficiency ratio } \\
(p \leq 0.05)\end{array}$ \\
\hline [95] & Live larvae & - & - & Free range chickens & $\begin{array}{l}\text { Weight gain }(p \leq 0.05) \\
\text { Clutch size }(p \leq 0.05) \\
\text { Hatchability }(p \leq 0.05) \\
\text { Egg weight }(p \leq 0.05) \\
\text { Chick weight }(p \leq 0.05)\end{array}$ \\
\hline [83] & $\begin{array}{l}0 \\
5 \\
10 \\
15 \\
\text { (Brooding } \\
\text { phase) } \\
\text { and } \\
0 \\
50 \\
100 \text { (Grow- } \\
\text { er-finisher } \\
\text { phase) }\end{array}$ & Fish meal & $\begin{array}{l}\text { 4.5\% (Brooding } \\
\text { phase) } \\
\text { 2\% (Grower-finisher } \\
\text { phase) }\end{array}$ & $\begin{array}{l}\text { Arbor Acers broiler chick- } \\
\text { ens }\end{array}$ & $\begin{array}{l}15 \% \text { HFM improved weight gain }(p \leq 0.05) \text {, feed } \\
\text { intake }(p \leq 0.05) \text {, FCR }(p \leq 0.05) \text { and feed cost } \\
(p \leq 0.05) \text { at brooding phase } \\
50 \% \text { HFM increased the feed intake }(p \leq 0.05) \\
\text { and abdominal fat }(p \leq 0.05) \text { at grower-finisher } \\
\text { phase } \\
100 \% \text { HFM improved the weight gain }(p \leq 0.05) \text {, } \\
\text { FCR }(p \leq 0.05) \text {, feed cost }(p \leq 0.05) \text {, carcass } \\
\text { yield ( } p \leq 0.05) \text {, heart percentage }(p \leq 0.05) \text {, } \\
\text { liver percentage ( } p \leq 0.05) \text {, gizzard percentage } \\
\text { ( } p \leq 0.05) \text { and leg percentage }(p \leq 0.05) \text { at grow- } \\
\text { er-finisher phase }\end{array}$ \\
\hline [96] & - & Fish meal & - & Qingyuan chickens & HFM improved meat quality \\
\hline [81] & $\begin{array}{l}0 \\
50 \text { (Dried) } \\
100 \text { (Dried } \\
\text { and fresh) }\end{array}$ & Fish meal & $\begin{array}{l}5 \% \text { (Starter phase) } \\
3 \% \text { (Grower phase) }\end{array}$ & Hybro-G broiler chickens & $\begin{array}{l}\text { Fresh HF larvae improved the body weight } \\
(p \leq 0.05) \text { and weight gain }(p \leq 0.05) \\
100 \% \text { dried HFM improved weight gain } \\
(p \leq 0.05) \text { at } 22 \text { to } 35 \text { day }\end{array}$ \\
\hline
\end{tabular}

HFM, housefly meal; FCR, feed conversion ratio.

$50 \%$ (5\% in diet) or $100 \%$ (10\% in diet) grasshopper meal as fish meal replacer exhibited improved growth [100]. Grasshopper meal completely and successfully replaced fish meal in the diet of Anak 2000 broiler chickens without any effect
[102] (Table 2). Qinjiaoma broiler chicken fed on the grasshoppers in pasture system resulted in increased heme iron, nonheme iron, total iron and $\alpha$-tocopherol contents, and activities of glutathione peroxidase and superoxidase dismutase

Table 2. Application of Orthoptera meal with different addition levels in broilers

\begin{tabular}{lcccccc}
\hline Reference & Inclusion level (\%) & Specie & $\begin{array}{c}\text { Replacement/ } \\
\text { alternative of }\end{array}$ & $\begin{array}{c}\text { Percentage } \\
\text { in diet }\end{array}$ & Poultry type & Results \\
\hline 102$]$ & 0 & Chinese grasshopper & Fish meal & $10 \%$ & Arbor acres broiler & Successfully replaced with \\
& 5 & (Acrida chinerea) & & & & no significant effect \\
& 10 & & & & & \\
\hline
\end{tabular}


of breast and leg muscle compared to broiler chickens fed on control diet in cage system [103]. Isa Brown laying hens fed on diet containing 25\% grasshopper (Ornithacris cavroisi) meal as a replacement for fish meal had improve Haugh unit, and diet containing 75\% grasshopper (Ornithacris cavroisi) meal improved the egg yolk color [100]. Live grasshoppers fed to free range Qinjiaoma broiler chickens improved live weight, carcass composition, and total lipid, phospholipids, and anti-oxidative potential of meat [26]. Indigenous chicken fed on diet containing 50\% wild edible grasshopper (Ruspolia nitidual) meal as replacement for fish meal improved the FCR and EE apparent digestibility, and diet containing 100\% wild edible grasshopper (Ruspolia nitidual) meal improved the $\mathrm{CP}$ apparent digestibility; However, diet containing higher levels (above than 25\%) of wild edible grasshopper (Ruspolia nitidual) meal as a replacement of fish meal resulted in reduced feed intake in indigenous chickens [99].

However, chitin and chitosan in OTM are not easily absorbed and utilized. Cobb 500 male broiler chickens fed on the diet containing $0.05 \%$ cricket chitosan or $0.05 \%$ cricket chitin displayed a negatively affected intestinal morphology and a downregulated mRNA expression of some nutrient transporters (PepT1, EAAT3, SGLT1, and SGLT5) [104].

\section{SILKWORM MEAL}

The silkworm is the larva or caterpillar of a moth. The larvae spins the silk to make a cocoon where it pupates to the adult moth. Silkworms eat mulberry leaves and were native to northern China. The culture of silkworms is called sericulture. Silkworm meal is a good source of protein, fatty acids, amino acids, minerals and vitamins [105-107]. Silkworm contains about $71.9 \%$ CP [107] $45.87 \%$ for spun silkworm pupae and $50.31 \%$ for reeling silkworm pupae [108]. Silkworm chitin which is a component of exoskeleton, contains approximately $25 \% \mathrm{CP}$, it does not contain amino acids and is not digestible [107]. The reported values for fat are $20.1 \%$ for silkworm pupae meal [107], 7.94\% for spun silkworm pupae and $25.76 \%$ for reeling silkworm pupae [108], 54\% $\mathrm{CP}$ and $2.5 \%$ crude fat [64].

Different content of silkworm meal (SWM) can be used in poultry feed to replace fish meal or soybean meal. Silkworm meal successfully substituted for fish meal or soybean meal in the diet of broiler chickens with no significant effect [107109]. Soybean meal was successfully and completely replaced by SWM in the diet of white leg horn hens without any effect [110].

Sonali chickens fed on the diet containing 25\% SWM as replacement of soybean meal increased the weight gain, feed intake, heart percentage, breast meat yield, and reduced breast meat protein percentage and ash percentage; $50 \%$ SWM increased the meat $\mathrm{pH}$, and n-3 PUFAs, and reduced the n-6 PUFAs of breast meat [111]. In addition, diet containing $75 \%$ SWM as replacement of soybean meal fed to Ross 308 broiler chicken resulted in increased body weight, feed intake, gross return/bird and profit/kg meat, and reduced cost/kg meat; $100 \%$ SWM has the opposite effect, and 25\% SWM in diet reduced the feed intake and increased the cost $/ \mathrm{kg}$ meat; $50 \%$ SWM reduced profit/kg meat [112] Table 3 lists the typical results of silkworm meal application in broilers.

\section{EARTHWORM MEAL AND VERMI- HUMUS}

Earthworm meal (EWM) is rich source of protein, energy, and amino acids [113-115]. The concentration of CP in EWM ranged from $41 \%$ to $66 \%$, and crude fat ranged from $3.5 \%$ to $18 \%$. Reported values for CP are $63.06 \%$ [115], $65.68 \%$ for (Eisenia foetida) [116,118], 7.27\% for vermi-humus [118], $55.87 \%$ [113], 57.85\% [117], and 41.42\% [114], and reported

Table 3. Application of silkworm meal with different addition levels in broilers

\begin{tabular}{|c|c|c|c|c|c|}
\hline References & $\begin{array}{l}\text { Inclusion } \\
\text { level (\%) }\end{array}$ & $\begin{array}{l}\text { Replacement/ } \\
\text { Alternative of }\end{array}$ & $\begin{array}{l}\text { Percentage } \\
\text { in diet }\end{array}$ & Poultry type & Results \\
\hline [109] & $\begin{array}{c}0 \\
25 \\
50 \\
75 \\
100\end{array}$ & Fish meal & $6.87 \%$ & Anak broiler chickens & Successfully replaced with no significant effect \\
\hline [110] & $\begin{array}{l}0 \\
6 \\
8\end{array}$ & - & - & RIR layer hens & $\begin{array}{l}6 \% \text { SWM improved the live weight }(p \leq 0.05) \text { and FCR } \\
(p \leq 0.05) \text {, egg production }(p \leq 0.05) \text { and reduced the feed } \\
\text { intake }(p \leq 0.05) \text { and feed cost }(p \leq 0.05) \\
8 \% \text { SWM improved the survivability }(p \leq 0.05)\end{array}$ \\
\hline [111] & $\begin{array}{c}0 \\
33 \\
66 \\
100\end{array}$ & Fish meal & $6 \%$ & Arbor Acers broiler chickens & $\begin{array}{l}100 \% \text { SWM improved live weight }(p \leq 0.05) \text {, FCR }(p \leq 0.05) \\
\text { and profitability }(p \leq 0.05) \text {, and reduced feed intake } \\
(p \leq 0.05)\end{array}$ \\
\hline
\end{tabular}

SWM, silkworm meal; RIR, Rhode Island red; FCR, feed conversion ratio. 
values for crude fat are 18.5\% [115], 16.39\% [113], 9.2\% [114], and 3.5\% [117]. Fresh earthworm (EW; Lumbricus rubellus) contains $6.89 \% \mathrm{CP}$ and $2.25 \%$ crude fat [114]. It is generally believed that the CP content in earthworms is between $50 \%$ and $70 \%$, and the crude fat content is less than $20 \%$, and its content is related to the freshness and dryness of the earthworms. In addition, EW products are often used in poultry feed in the form of EWM or a mixture of EWM and vermihumus.

Feeding broilers with feed supplemented with $1 \%$ EWM and $1 \%$ vermi-humus has a negative impact on the growth performance of broilers, although the immune functions were improved [118]. But the feed supplemented with 3\% EWM and 1\% vermi-humus can improve the performance of broilers and increase relative weight of immune organs, intestinal length, and intestinal lactic acid bacteria count [116]. Hybro G female broiler chickens fed on fresh EW (Lumbricus rubellus) diet improved the quality of meat for thigh and breast; in addition, diet containing 100\% EWM ( $8 \%$ for 1 to $21 \mathrm{~d}, 5 \%$ for 22 to $35 \mathrm{~d}$ ) as a replacement for fish meal reduced the fat content of breast, and thigh meat, and exhibited the higher acceptability of drumsticks [114]. Ningdu yellow female broiler chickens fed on diet containing 5\% EWM had improved growth performance and antioxidant capacity [117].

Diet containing 3\% EWM (Eudrilus eugeniae) improved the body weight gain, and diet containing 5\% EWM improved the FCR and increased meat $\mathrm{pH}$; and diet containing 7\% EWM improved aroma, juiciness, residues, and flavor of the meat in Cobb 500 broiler chickens [119]. Ross 308 broiler chickens fed on the diet containing $2 \%, 4 \%$, or $6 \%$ EWM increased the breast meat yield, high density lipoprotein level and reduced the low-density lipoprotein level, and increased body weight and feed intake were observed in diet containing $2 \%$ or 4\% EWM [120]. It was reported that soybean and fish meals could be replaced partially with EWM between $10 \%$ to $15 \%$ in the broiler diets [121] (Table 4).

\section{TERMITE MEAL}

Termite (Sclerotized macropterous) meal contains about $42.33 \%$ $\mathrm{CP}$ after Sun drying and $47.34 \% \mathrm{CP}$ after roasting, and about
$41 \%$ crude fat [122].

Termites (Macrotermes subhyalinus and Macrotermes bellicosus) were successfully substituted in dry or fresh form in the diet of indigenous chickens without any effect [123]. Inclusion of termites (Glyptotermes montanus) extracted endo$\beta$-D-1,4-glucanase, avicelase, $\beta$-D-1,4-mannanase, $\beta$-D-1,4xylanase and $\beta$-D-1,4-glucosidase enzymes in poultry diet can improve digestion in poultry [124].

\section{BEE MEAL}

Bee slum contains about 9.37\% CP and 54.9\% crude fat [125]. Bee products are mainly used in poultry feed in three forms: bee propolis, bee pollen and bee slum. The appropriate dosage of bee products can influence the performance of broiler chickens, and a lower dose of Bee products can have a good growth-promoting effect when applied in poultry feed.

Ross 308 broiler chickens fed on the diet containing $0.025 \%$ bee propolis and $2 \%$ bee pollen increased carcass yield and reduced drip loss, skin yellowness, breast meat yellowness: and $0.05 \%$ bee propolis increased carcass yield and reduced drip loss, skin yellowness, breast meat yellowness [126]. Dietary addition of $0.05 \%$ to $0.1 \%$ bee propolis or $2 \%$ bee pollen increased the duodenal villi height, duodenal villi base width, villus height crypt depth ratio and reduced the duodenal villi crypt depth in broiler [127]. Diet containing 0.04\% ethanol extracted bee propolis fed to Ross 308 broiler chickens increased the concentrations of glutamic acid, glycine and tyrosine in breast muscle, and aspartic acid, serine, alanine, tyrosine, histidine, and threonine in thigh muscle, and reduced the concentration of methionine in breast muscle and proline in thigh muscle; however, $0.04 \%$ ethanol extracted bee pollen reduced proline concentration in breast muscle [128]. Diet containing $(0.04 \%$ or $0.08 \%)$ bee pollen fed to Ross 308 broiler chickens did not affect the blood mineral profile [129].

Ross 308 broiler chickens fed on the diet containing $0.04 \%$ bee pollen resulted in increased body weight and carcass weight [130]. Diet containing $25 \%$ or $50 \%$ bee slum as a replacement of corn in the diet of Anak 2000 broiler chickens reduced the body weight and feed intake and increased the pancreas percentage [125]. Ross 308 boiler chickens at week

Table 4. Application of earthworm meal with different addition levels in broilers

\begin{tabular}{|c|c|c|c|c|c|c|}
\hline References & $\begin{array}{l}\text { Inclusion } \\
\text { level (\%) }\end{array}$ & Specie & $\begin{array}{l}\text { Replacement/ } \\
\text { alternative of }\end{array}$ & $\begin{array}{l}\text { Percentage } \\
\text { in diet }\end{array}$ & Poultry type & Results \\
\hline [121] & $\begin{array}{c}0 \\
5 \\
10 \\
15 \\
20\end{array}$ & $\begin{array}{l}\text { Lumbricus rubellus, } \\
\text { Perionyx excavatus }\end{array}$ & - & - & $\begin{array}{l}\text { Ross male broiler } \\
\text { chickens }\end{array}$ & $\begin{array}{l}10 \% \text { EWM improved body weight }(p \leq 0.05) \\
5 \% \text { EWM improved feed intake }(p \leq 0.05) \\
15 \% \text { EWM improved FCR }(p \leq 0.05) \\
20 \% \text { EWM reduced the fecal lactic acid } \\
\text { bacteria count }(p \leq 0.05)\end{array}$ \\
\hline
\end{tabular}

EWM, earthworm meal; FCR, feed conversion ratio. 
3 exhibited improved body weight and feed intake when fed on diet containing 2,000 ppm pine originated bee propolis; however, diet containing 4,000 ppm have the opposite effect. Thus. higher level of pine originated bee propolis had adverse effect on growth performance and protein digestibility [131].

Lohmann LSL laying hens fed on the diet containing $0.025 \%$ and $0.05 \%$ bee propolis increased the egg mass, egg production, Haugh unit, albumen height, yolk height, yolk index, yolk weight, blood total protein, blood globulin, hemoglobin, lymphocytes and reduced FCR, yolk diameter, blood cholesterol, heterophil, heterophil lymphocyte ratio [132]. Diet containing $0.05 \%$ and $0.15 \%$ bee pollen fed to Sinai laying hens increased the egg number, egg mass, production percentage, feed intake, red blood cells, white blood cells, lymphocytes and reduced the body weight, weight gain, heterophils, heterophil lymphocyte ratio, blood cholesterol, blood triglycerides; however, diets containing $0.1 \%$ bee pollen have the opposite effect [133].

\section{CHALLENGE AND PERSPECTIVES}

Although considerable studies have been conducted in broilers and laying hens, there are still some obstacles to the proper and efficient utilization of insect meal in poultry industry. The quality and nutrient profile of insect products varied with the differences in insect species, rearing medium, environment, and processing method. The absence of large-scale production and stable supply of insect meal do not favor the accurate evaluation of metabolizable energy and effective nutrient availability. Furthermore, the processing method needs to be updated for cost reduction of insect products, and risk reduction of pathogenic contamination and disease spreading. With the availability of quality and stable insect meals, more reliable efficacy studies may be performed to evaluate the health, immunomodulatory and functional effects of insect meals compared with the alternative protein feedstuffs.

In the current environment with studies of insect meal in broiler and laying hens, BSFM, MWM, and HFM exhibit the most promising industrialization prospects. However, earthworm, silkworm, and locust swarms can be effectively utilized in poultry feed. Because insects are used as medium of medicines for centuries, it is reasonable to believe that insects can be used in poultry diet to replace antibiotics because of their antimicrobial properties. Insect meal can also be used in low CP diets for amino acids adjustment as insects are enriched in essential amino acids. With the emergence of more accurate and reliable studies, insect meal will inevitably play a greater role in the poultry feed industry.

\section{CONFLICT OF INTEREST}

We certify that there is no conflict of interest with any financial organization regarding the material discussed in the manuscript.

\section{FUNDING}

The authors are grateful for the support by Beijing Innovation Consortium of Agriculture Research System Poultry-related Science and Technology Team (CARS-PSTP), Shandong Key Science and Technology Innovation Program (2019 JZZY010704) and Agricultural Science and Technology Innovation Program of the Chinese Academy of Agricultural Sciences (CAAS-ASTPI-2017-FRI-03).

\section{REFERENCES}

1. Chavez M, Uchanski M. Insect left-over substrate as plant fertiliser. J Insects Food Feed 2021;7:683-694. https://doi.org/ 10.3920/JIFF2020.0063

2. Slade EM, Riutta T, Roslin T, Tuomisto HL. The role of dung beetles in reducing greenhouse gas emissions from cattle farming. Sci Rep-Uk 2021;6:18140. https://doi.org/10.1038/ srep 18140

3. Veldkamp T, Bosch G. Insects - a protein rich feed ingredient in pig and poultry diets. Anim Front 2015;5:45-50.

4. Al-qazzaz MF, Ismail DB. Insect meal as a source of protein in animal diet. Anim Nutr Feed Technnol 2016;16:527-547. https://doi.org/10.5958/0974-181X.2016.00038.X

5. Khan SH. Recent advances in role of insects as alternative protein source in poultry nutrition. J Appl Anim Res 2018; 46:1144-57. https://doi.org/10.1080/09712119.2018.1474743

6. Elahi U, Wang J, Ma Y, et al. Evaluation of yellow mealworm meal as a protein feedstuff in the diet of broiler chicks. Animals 2020;10:224. https://doi.org/10.3390/ani10020224

7. Kröncke N, Grebenteuch S, Keil C, et al. Effect of different drying methods on nutrient quality of the yellow mealworm (Tenebrio molitor L.). Insects 2019;10:84. https://doi.org/ 10.3390/insects10040084

8. Gasco L, Finke M, van Huis A. Can diets containing insects promote animal health? J Insects Food Feed 2018;4:1-4. https:// doi.org/10.3920/JIFF2018.x001

9. Lee CG, Da Silva CA, Lee JY, Hartl D, Elias JA. Chitin regulation of immune responses: an old molecule with new roles. Curr Opin Immunol 2008;20:684-689. https://doi.org/10. 1016/j.coi.2008.10.002

10. Chu X, Li M, Wang G, et al. Evaluation of the low inclusion of full-fatted hermetia illucens larvae meal for layer chickens: growth performance, nutrient digestibility, and gut health. Front Vet Sci 2020;7:585843. https://doi.org/10.3389/fvets. 2020.585843 
11. Schiavone A, De Marco M, Martínez S, et al. Nutritional value of a partially defatted and a highly defatted black soldier fly larvae (Hermetia illucens L.) meal for broiler chickens: apparent nutrient digestibility, apparent metabolizable energy and apparent ileal amino acid digestibility. J Anim Sci Biotechnol 2017;8:51. https://doi.org/10.1186/ s40104-017-0181-5

12. Bovera F, Piccolo G, Gasco L, et al. Yellow mealworm larvae (Tenebrio molitor, L.) as a possible alternative to soybean meal in broiler diets. Br Poult Sci 2015;56:569-575. https:// doi.org/10.1080/00071668.2015.1080815

13. Khempaka S, Chitsatchapong C, Molee W. Effect of chitin and protein constituents in shrimp head meal on growth performance, nutrient digestibility, intestinal microbial populations, volatile fatty acids, and ammonia production in broilers. J Appl Poult Res 2011;20:1-11. https://doi.org/10.3382/japr. 2010-00162

14. Menconi A, Pumford NR, Morgan MJ, et al. Effect of chitosan on Salmonella Typhimurium in broiler chickens. Foodborne Path Dis 2014;11:165. https://doi.org/10.1089/fpd.2013.1628

15. Makkar HPS, Tran G, Heuzé V, Ankers P. State-of-the-art on use of insects as animal feed. Anim Feed Sci Technol 2014;197:1-33. https://doi.org/10.1016/j.anifeedsci.2014.07. 008

16. Eilenberg J, Vlak JM, Nielsen-LeRoux C, Cappellozza S, Jensen $\mathrm{AB}$. Diseases in insects produced for food and feed. J Insects Food Feed 2015;1:87-102. https://doi.org/10.3920/JIFF2014. 0022

17. Józefiak A, Engberg RM. Insect proteins as a potential source of antimicrobial peptides in livestock production. A review. J Anim Feed Sci 2017;26:87-99. https://doi.org/10.22358/jafs/ 69998/2017

18. Mancini S, Fratini F, Tuccinardi T, Degl'Innocenti C, Paci G. Tenebrio molitor reared on different substrates: is it gluten free? Food Control 2020;110:107014. https://doi.org/10.1016/ j.foodcont.2019.107014

19. Charlton AJ, Dickinson M, Wakefield ME, et al. Exploring the chemical safety of fly larvae as a source of protein for animal feed. J Insects Food Feed 2015;1:7-16. https://doi. org/10.3920/JIFF2014.0020

20. Choi YC, Park KH, Nam SH, et al. The effect on growth performance of chicken meat in broiler chicks by dietary supplementation of black soldier fly larvae, Hermetia illucens (Diptera: Stratmyidae). J Sericult Entomol Sci 2013;51:30-35. https:// doi.org/10.7852/jses.2013.51.1.30

21. Wang S, Zeng X, Yang Q, Qiao S. Antimicrobial peptides as potential alternatives to antibiotics in food animal industry. Int J Mol Sci 2016;17:603. https://doi.org/10.3390/ijms170 50603

22. Van Huis A. Insects as food and feed, a new emerging agricultural sector: a review. J Insects Food Feed 2020;6:27-44. https://doi.org/10.3920/JIFF2019.0017
23. Nekrasov RV, Zelenchenkova AA, Chabaev MG, Ushakova NA. Melanine protein-energy additive from Hermetia illucens larvae in nutrition of calves. Sel'skokhozyaistvennaya Biol 2018;53:374-384. https://doi.org/10.15389/agrobiology.2018. 2.374eng

24. Ushakova NA, Dontsov AE, Sakina NL, et al. Melanin and melanogenesis at different life stages in Hermetia illucens. Biol Bull 2018;45:47-50.

25. Lieberman S, Enig MG, Preuss HG. A review of monolaurin and lauric acid: Natural virucidal and bactericidal agents. Altern Complement Ther 2006;12:310-314. http://doi.org/10. 1089/act.2006.12.310

26. Sun T, Long RJ, Liu ZY. The effect of a diet containing grasshoppers and access to free-range on carcase and meat physicochemical and sensory characteristics in broilers. Br Poult Sci 2013;54:130-137. https://doi.org/10.1080/00071668.2012. 756575

27. Iqbal A, Qudoos A, Çetingül IS, Shah SRA, Bayram I. Insects as alternative feed materials for poultry nutrition. J Anim Sci Prod 2019;2:30-37.

28. Kawasaki K, Hashimoto Y, Hori A, et al. Evaluation of black soldier fly (Hermetia illucens) larvae and Pre-Pupae raised on household organic waste, as potential ingredients for poultry feed. Animals 2019;9:98. https://doi.org/10.3390/ ani9030098

29. Nyakeri EM, Ogola HJ, Ayieko MA, Amimo FA. An open system for farming black soldier fly larvae as a source of proteins for smallscale poultry and fish production. J Insects Food Feed 2017;3:51-6. https://doi.org/10.3920/JIFF2016. 0030

30. Liu X, Liu X, Yao Y, et al. Effects of different levels of Hermetia illucens larvae meal on performance, egg quality, yolk fatty acid composition and oxidative status of laying hens. Ital J Anim Sci 2021;20:256-266. https://doi.org/10.1080/182805 1X.2021.1878946

31. De Marco M, Martínez S, Hernandez F, et al. Nutritional value of two insect larval meals (Tenebrio molitor and Hermetia illucens) for broiler chickens: Apparent nutrient digestibility, apparent ileal amino acid digestibility and apparent metabolizable energy. Anim Feed Sci Technol 2015;209:211-218. https:// doi.org/10.1016/j.anifeedsci.2015.08.006

32. Vilela J de S, Alvarenga TIRC, Andrew NR, et al. Technological quality, amino acid and fatty acid profile of broiler meat enhanced by dietary inclusion of black soldier fly larvae. Foods 2021;10:297. https://doi.org/10.3390/foods10020297

33. Mohammed A, Laryea TE, Ganiyu A, Adongo T. Effects of black soldier fly (hermetia illucens) larvae meal on the growth performance of broiler chickens. Intl J Dev 2017;4:35-41.

34. Onsongo VO, Osuga IM, Gachuiri CK, et al. Insects for income generation through animal feed: effect of dietary replacement of soybean and fish meal with black soldier fly meal on broiler growth and economic performance. J Econ 
Entomol 2018;111:1966-1973. https://doi.org/10.1093/jee/ toy118

35. Biasato I, Ferrocino I, Dabbou S, et al. Black soldier fly and gut health in broiler chickens: insights into the relationship between cecal microbiota and intestinal mucin composition. J Anim Sci Biotechnol 2020;11:1-12.

36. Mwaniki Z, Neijat M, Kiarie E. Egg production and quality responses of adding up to $7.5 \%$ defatted black soldier fly larvae meal in a corn-soybean meal diet fed to Shaver White Leghorns from wk 19 to 27 of age. Poult Sci 2018;97:28292835. https://doi.org/10.3382/ps/pey118

37. Neumann C, Velten S, Liebert F. Improving the dietary protein quality by amino acid fortification with a high inclusion level of micro algae (Spirulina platensis) or insect meal (Hermetia illucens) in meat type chicken diets. Open J Anim Sci 2018;8: 12-26. https://doi.org/10.4236/ojas.2018.81002

38. Neumann C, Velten S, Liebert F. The graded inclusion of algae (Spirulina platensis) or insect (Hermetia illucens) meal as a soybean meal substitute in meat type chicken diets impacts on growth, nutrient deposition and dietary protein quality depending on the extent of amino acid Supplementation. Open J Anim Sci 2018;8:163-183. https://doi.org/10.4236/ ojas.2018.82012

39. Brede A, Wecke C, Liebert F. Does the optimal dietary methionine to cysteine ratio in diets for growing chickens respond to high inclusion rates of insect meal from Hermetia illucens? Animals 2018;8:187. https://doi.org/10.3390/ani8110187

40. Rothstein S. Potential of Hermetia illucens larvae meal as protein source in broiler diets [Internet]. Lohmann Information [cited 2021 Sept 18]. Available from: https://lohmann-breeders. com/lohmanninfo/potential-of-hermetia-illucens-larvaemeal-as-protein-source-in-broiler-diets/

41. Moula N, Scippo ML, Douny C, et al. Performances of local poultry breed fed black soldier fly larvae reared on horse manure. Anim Nutr 2018;4:73-78. https://doi.org/10.1016/ j.aninu.2017.10.002

42. Oonincx DGABAB. Insects as food and feed: Nutrient composition and environmental impact. Wageningen, The Netherlands: Wageningen University; 2015.

43. Newton GL, Sheppard DC, Watson DW, et al. The black soldier fly, Hermetia illucens, as a manure management / resource recovery tool. In: Symposium on the state of the science of Animal Manure and Waste Management; 2005. 57 p.

44. Van Huis A. Edible insects. Future prospects for food and feed security [Internet]. Vol. 171, Rome, Italy: Food and Agriculture Organization of the United Nations; 2013. 201 p. Available from: http://www.fao.org/3/i3253e/i3253e00.htm

45. Veldkamp T, van Duinkerken G, van Huis A, et al. Insects as a sustainable feed ingredient in pig and poultry diets - a feasibility study. Wageningen, The Netherlands: Wageningen UR Livestock Research; 2012.

46. Dahiru S, Azhar B, Anjas AB. Performance of Spring chicken fed different inclusion levels of black soldier fly larvae meal. Entomol Ornithol Herpetol 2016;5:185. https://doi.org/10. 4172/2161-0983.1000185

47. Schiavone A, Dabbou S, Petracci M, et al. Black soldier fly defatted meal as a dietary protein source for broiler chickens: effects on carcass traits, breast meat quality and safety. Animal 2019;13:2397-2405. https://doi.org/10.1017/S1751731119 000685

48. Dabbou S, Gai F, Biasato I, et al. Black soldier fly defatted meal as a dietary protein source for broiler chickens: effects on growth performance, blood traits, gut morphology and histological features. J Anim Sci Biotechnol 2018;9:49. https:// doi.org/10.1186/s40104-018-0266-9

49. Kareem KY, Abdulla NR, Foo HL, et al. Effect of feeding larvae meal in the diets on growth performance, nutrient digestibility and meat quality in broiler chicken. Indian J Anim Sci 2018;88:1180-1185.

50. Lee J, Kim YM, Park YK, Yang YC, Jung BG, Lee BJ. Black soldier fly (Hermetia illucens) larvae enhances immune activities and increases survivability of broiler chicks against experimental infection of Salmonella Gallinarum. J Vet Med Sci 2018;80:736-740. https://doi.org/10.1292/jvms.17-0236

51. Manangkot HJ, Rondonuwu SJ, Pinontoan OR, Najoan M, Rumokoy JM. Black soldier fly larvae manure degradation as fish meal replacer in native chicken ration. Lucrări Ştiinţifice - Seria Zootehnie 2014;62:139-142.

52. Mohammed A. Evaluation of black soldier fly (Hermetia illucens) larvae meal as an alternative protein source in broiler chicken diets: effect on carcass and eating quality of broiler chicken. Research \& Reviews: J Food Sci Technol 2017;6:1821.

53. Pieterse E, Erasmus S, Hoffman LC. Black soldier fly (Hermetia illucens) pre-pupae meal as a dietary protein source for broiler production ensures a tasty chicken with standard meat quality for every pot. J Sci Food Agric 2019;99:893-903. https://doi. org/10.1002/jsfa.9261

54. Schiavone A, Dabbou S, De Marco M, et al. Black soldier fly larva fat inclusion in finisher broiler chicken diet as an alternative fat source. Animal 2018;12:2032-2039. https:/doi.org/ $10.1017 /$ S1751731117003743

55. Schiavone A, Cullere M, De Marco M, et al. Partial or total replacement of soybean oil by black soldier fly larvae (Hermetia illucens L.) fat in broiler diets: effect on growth performances, feed-choice, blood traits, carcass characteristics and meat quality. Ital J Anim Sci 2017;16:93-100. https://doi.org/10. 1080/1828051X.2016.1249968

56. Cullere M, Schiavone A, Dabbou S, Gasco L, Dalle Zotte A. Meat quality and sensory traits of finisher broiler chickens fed with black soldier fly (Hermetia Illucens L.) larvae fat as alternative fat source. Animals 2019;9:140. https://doi.org/10. 3390/ani9040140

57. Leiber F, Gelencsér T, Stamer A, et al. Insect and legume- 
based protein sources to replace soybean cake in an organic broiler diet: Effects on growth performance and physical meat quality. Renew Agric Food Syst 2017;32:21-7. https:// doi.org/10.1017/S1742170515000496

58. Heuel M, Sandrock C, Leiber F, et al. Black soldier fly larvae meal and fat can completely replace soybean cake and oil in diets for laying hens. Poult Sci 2021;100:101034. https://doi. org/10.1016/j.psj.2021.101034

59. Marono S, Loponte R, Lombardi P, et al. Productive performance and blood profiles of laying hens fed Hermetia illucens larvae meal as total replacement of soybean meal from 24 to 45 weeks of age. Poult Sci 2017;96:1783-90. https://doi. org/10.3382/ps/pew461

60. Maurer V, Holinger M, Amsler Z, et al. Replacement of soybean cake by Hermetia illucens meal in diets for layers. J Insects Food Feed 2016;2:83-90. https://doi.org/10.3920/ JIFF2015.0071

61. Zadeh ZS, Kheiri F, Faghani M. Use of yellow mealworm (Tenebrio molitor) as a protein source on growth performance, carcass traits, meat quality and intestinal morphology of Japanese quails (Coturnix japonica). Vet Anim Sci 2019;8: 100066. https://doi.org/10.1016/j.vas.2019.100066

62. Sedgh-Gooya S, Torki M, Darbemamieh M, Khamisabadi H, Karimi Torshizi MA, Abdolmohamadi A. Yellow mealworm, Tenebrio molitor (Col: Tenebrionidae), larvae powder as dietary protein sources for broiler chickens: Effects on growth performance, carcass traits, selected intestinal microbiota and blood parameters. J Anim Physiol Anim Nutr 2021; 105:119-28. https://doi.org/10.1111/jpn.13434

63. Benzertiha A, Kierończyk B, Kołodziejski P, et al. Tenebrio molitor and Zophobas morio full-fat meals as functional feed additives affect broiler chickens' growth performance and immune system traits. Poult Sci 2020;99:196-206. https:// doi.org/10.3382/ps/pez450

64. Khan S, Khan RU, Alam W, Sultan A. Evaluating the nutritive profile of three insect meals and their effects to replace soya bean in broiler diet. J Anim Physiol Anim Nutr 2018;102: e662-8. https://doi.org/10.1111/jpn.12809

65. Islam MM, Yang CJ. Efficacy of mealworm and super mealworm larvae probiotics as an alternative to antibiotics challenged orally with Salmonella and E. coli infection in broiler chicks. Poult Sci 2017;96:27-34. https://doi.org/10. 3382/ps/pew220

66. Hussain I, Khan S, Sultan A, et al. Meal worm (Tenebrio molitor) as potential alternative source of protein supplementation in broiler. Int J Biosci 2017;10:255-62.

67. Benzertiha A, Kierończyk B, Rawski M, et al. Tenebrio molitor and Zophobas morio full-fat meals in broiler chicken diets: effects on nutrients digestibility, digestive enzyme activities, and cecal microbiome. Animals 2019;9:1128. https:/doi.org/ 10.3390/ani9121128

68. Biasato I, Ferrocino I, Grego E, et al. Gut microbiota and mucin composition in female broiler chickens fed diets including yellow mealworm (Tenebrio molitor, L.). Animals 2019; 9:213. https://doi.org/10.3390/ani9050213

69. Dabbou S, Gasco L, Lussiana C, et al. Yellow mealworm (Tenebrio molitor L.) larvae inclusion in diets for free-range chickens: effects on meat quality and fatty acid profile. Renew Agric Food Syst 2020;35:571-8. https://doi.org/10.1017/S1742 170519000206

70. Loponte R, Bovera F, Piccolo G, et al. Fatty acid profile of lipids and caeca volatile fatty acid production of broilers fed a full fat meal from Tenebrio molitor larvae. Ital J Anim Sci 2019;18:168-73. https://doi.org/10.1080/1828051X.2018. 1502053

71. Biasato I, Gasco L, De Marco M, et al. Yellow mealworm larvae (Tenebrio molitor) inclusion in diets for male broiler chickens: effects on growth performance, gut morphology, and histological findings. Poult Sci 2018;97:540-8. https:// doi.org/10.3382/ps/pex308

72. Biasato I, Gasco L, De Marco M, et al. Effects of yellow mealworm larvae (Tenebrio molitor) inclusion in diets for female broiler chickens: implications for animal health and gut histology. Anim Feed Sci Technol 2017;234:253-63.

73. Biasato I, De Marco M, Rotolo L, et al. Effects of dietary Tenebrio molitor meal inclusion in free-range chickens. J Anim Physiol Anim Nutr 2016;100:1104-12. https://doi.org/ 10.1111/jpn.12487

74. Bovera F, Loponte R, Marono S, et al. Use of Tenebrio molitor larvae meal as protein source in broiler diet: Effect on growth performance, nutrient digestibility, and carcass and meat traits. J Anim Sci 2016;94:639-47. https://doi.org/10.2527/ jas.2015-9201

75. Kim SG, Kim JE, Oh HK, et al. Feed supplementation of yellow mealworms (Tenebrio molitor L.) improves blood characteristics and meat quality in broiler. J Agric Sci Technol 2014; 49:9-18. https://doi.org/10.29335/tals.2014.49.9

76. Ballitoc DA, Sun S. Ground yellow mealworms (Tenebrio molitor L.) feed supplementation improves growth performance and carcass yield characteristics in broilers. Open Sci Reposit Agric 2013;e23050425. https://doi.org/10.7392/ openaccess. 23050425

77. Hall HN, O'Neill HVM, Scholey D, et al. Amino acid digestibility of larval meal (Musca domestica) for broiler chickens. Poult Sci 2018;97:1290-7. https://doi.org/10.3382/ps/pex433

78. Radulović S, Pavlović M, Šefer D, et al. Effects of housefly larvae (Musca domestica) dehydrated meal on production performances and sensory properties of broiler meat. Thai J Vet Med 2018;48:63-70.

79. Awoniyi TAM, Aletor VA, Aina JM. Performance of broiler - Chickens fed on maggot meal in place of fishmeal. Int J Poult Sci 2003;2:271-4.

80. Khan S, Khan RU, Sultan A, Khan M, Hayat SU, Shahid MS. Evaluating the suitability of maggot meal as a partial substitute 
of soya bean on the productive traits, digestibility indices and organoleptic properties of broiler meat. J Anim Physiol Anim Nutr 2016;100:649-56. https://doi.org/10.1111/jpn. 12419

81. Đorđević M, Radenković-Damnjanović B, Vučinić M, et al. Effects of substitution of fish meal with fresh and dehydrated larvae of the house fly (Musca domestica L) on productive performance and health of broilers. Acta Vet 2008;58:357-68.

82. Hwangbo J, Hong EC, Jang A, et al. Utilization of house flymaggots, a feed supplement in the production of broiler chickens. J Environ Biol 2009;30:609-14.

83. Téguia A, Mpoame M, Okourou Mba JA. The production performance of broiler birds as affected by the replacement of fish meal by maggot meal in the starter and finisher diets. Tropicultura 2002;20:187-92.

84. Okah U, Onwujiariri EB. Performance of finisher broiler chickens fed maggot meal as a replacement for fish meal. J Agric Technol 2012;8:471-7.

85. Mbiba HF, Etchu KA, Ndamukong K. Performance of broiler chickens fed maggot meal as a protein substitute for fish meal. J Ethol Anim Sci 2019;2:1-11.

86. Elahi U, Ma Y, Wu S, Wang J, Zhang H, Qi G. Growth performance, carcass characteristics, meat quality and serum profile of broiler chicks fed on housefly maggot meal as a replacement of soybean meal. J Anim Physiol Anim Nutr 2020;104:107584. https://doi.org/10.1111/jpn.13265

87. Dillak SYFG, Suryatni NPF, Handayani HT, et al. The effect of fed maggot meal as a supplement in the commercial diets on the performance of finisher broiler chickens. IOP Conf Series: Earth Environ Sci 2019;260:012056. https://doi.org/ 10.1088/1755-1315/260/1/012056

88. Aniebo AO, Erondu ES, Owen OJ. Proximate composition of housefly larvae (Musca domestica) meal generated from mixture of cattle blood and wheat bran. Livest Res Rural Dev 2008;20:Article \#205.

89. Aniebo AO, Owen OJ. Effects of age and method of drying on the proximate composition of housefly larvae (Musca domestica Linnaeus) meal (HFLM). Pak J Nutr 2010;9:485-7.

90. Khan M, Chand N, Khan S, Khan RU, Sultan A. Utilizing the house fly (Musca Domestica) larva as an alternative to soybean meal in broiler ration during the starter phase. Braz J Poult Sci 2018;20:9-14. https://doi.org/10.1590/1806-90612017-0529

91. Ren JL, Wu YB, Lin JR. Effect of house fly larvae meal on growth performance and slaughter performance of yellow dwarf chickens. China Poult 2011;33:8-11.

92. Pretorius Q. The evaluation of larvae of Musca domestica (common house fly) as protein source for broiler production. Stellenbosch, South Africa: Stellenbosch University; 2011.

93. Pieterse E, Pretorius Q, Hoffman LC, Drew DW. The carcass quality, meat quality and sensory characteristics of broilers raised on diets containing either Musca domestica larvae meal, fish meal or soya bean meal as the main protein source. Anim Prod Sci 2013;54:622-8. https://doi.org/10.1071/AN 13073

94. Chang B, Han RC, Cao L, Liu XFL, Liu XFL. Effect of Musca domestica maggot and pupae as feed additives on the quality and flavor of Qingyuan chickens. Chinese Bull Entomol 2007; 44:882-6.

95. Dankwa DF, Nelson SEO, Oddoye K, Duncan JL. Housefly larvae as a feed supplement for rural poultry. Ghana J Agric Sci 2002;35:185-7.

96. Agunbiade JA, Adeyemi OA, Ashiru OM, et al. Replacement of fish meal with maggot meal in cassava-based layers' diets. J Poult Sci 2007;44:278-82. https://doi.org/10.2141/jpsa. 44.278

97. Ghosh S, Haldar P, Mandal D. Evaluation of nutrient quality of a short horned grasshopper, Oxya hyla hyla Serville (Orthoptera: Acrididae) in search of new protein source. J Entomol Zool Stud 2016;4:193-7.

98. Wang D, Zhai SW, Zhang CX, Zhang Q, Chen H. Nutrition value of the Chinese grasshopper Acrida cinerea (Thunberg) for broilers. Anim Feed Sci Technol 2007;135:66-74. https:// doi.org/10.1016/j.anifeedsci.2006.05.013

99. Nginya ES, Ondiek JO, Kingori AM, Nduko JM. Evaluation of grasshoppers as a protein source for improved indigenous chicken growers. Livest Res Rurual Dev 2019;31:Article \#2.

100. Brah N, Issa S, Houndonougbo F. Effect of grasshopper meal on laying hens' performance and eggs quality characteristics. Indian J Anim Sci 2017;87:1005-10.

101. Amobi MI, Saleh A, Okpoko VO, Abdullahi AM. Growth performance of broiler chickens based on grasshopper meal inclusions in feed formulation. Zoologist 2020;18:39-43. https:// doi.org/10.4314/tzool.v18i1.7

102. Sanusi M, Garba A, Saidu I, Ali YZ. Performance of broiler chickens fed graded levels of grasshopper meals. Int J Appl Res Technol 2013;2:235-40.

103. Sun T, Long RJ, Liu ZY, Ding WR, Zhang Y. Aspects of lipid oxidation of meat from free-range broilers consuming a diet containing grasshoppers on alpine steppe of the tibetan plateau. Poult Sci 2012;91:224-31. https://doi.org/10.3382/ ps.2011-01598

104. Ibitoye EB, Lokman IH, Hezmee MNM, et al. Gut health and serum growth hormone levels of broiler chickens fed dietary chitin and chitosan from cricket and shrimp. Poult Sci 2019;98:745-52. https://doi.org/10.3382/ps/pey419

105. Longvah T, Mangthya K, Ramulu P. Nutrient composition and protein quality evaluation of eri silkworm (Samia ricinii) prepupae and pupae. Food Chem 2011;128:400-3. https:// doi.org/10.1016/j.foodchem.2011.03.041

106. Chieco C, Morrone L, Bertazza G, et al. The Effect of strain and rearing medium on the chemical composition, fatty acid profile and carotenoid content in Silkworm (Bombyx mori) 
pupae. Animals 2019;9:103. https://doi.org/10.3390/ani9030103

107. Acay RP. Silkworm pupa meal as feed supplement for growing-finishing broilers. Benguet, Philippines: Benguet State University; 2011.

108. Jintasataporn O. Production performance of broiler chickens fed with silkworm pupa (Bombyx mori). J Agric Sci TechnolIran 2012;2:505-10.

109. Ijaiya AT, Eko EO. Effect of replacing dietary fish meal with silkworm (anaphe infracta) caterpillar meal on performance, carcass characteristics and haematological parameters of finishing broiler chicken. Pak J Biol Sci2009;8:850-5.

110. Ullah R, Khan S, Khan N, et al. Replacement of soybean meal with silkworm meal in the diets of white leghorn layers and effects on performance, apparent total tract digestibility, blood profile and egg quality. Int J Vet Health Sci Res 2017;5: 200-7.

111. Miah MY, Singh Y, Cullere M, Tenti S, Dalle Zotte A. Effect of dietary supplementation with full-fat silkworm (Bombyx mori L.) chrysalis meal on growth performance and meat quality of Rhode Island Red $\times$ Fayoumi crossbred chickens. Ital J Anim Sci 2020;19:447-56. https://doi.org/10.1080/182 8051X.2020.1752119

112. Ullah R, Khan S, Hafeez A, et al. Silkworm (Bombyx mori) meal as alternate protein ingredient in broiler finisher ration. Pak J Zool 2017;49:1463-70.

113. Istiqomah L, Sakti AA, Suryani AE, Karimy MF, Anggraeni AS, Herdian H. Effect of feed supplement containing earthworm meal (Lumbricus rubellus) on production performance of quail (Coturnix coturnix japonica). IOP Conf Ser Earth Environ Sci 2017;101:012032. https://doi.org/10.1088/ 1755-1315/101/1/012032

114. Janković LJ, Petrujkić B, Aleksić N, et al. Carcass characteristics and meat quality of broilers fed on earthworm (Lumbricus rubellus) meal. J Hellenic Vet Med Soc 2020;71: 2031-40. https://doi.org/10.12681/jhvms.22953

115. Istiqomah L, Sofyan A, Damayanti E, Julendra H. Amino acid profile of earthworm and earthworm meal (Lumbricus Rubellus) for animal feedstuff. J Indonesian Trop Anim Agric 2009;34:253-7.

116. Chashmidari Y, Esmaielzadeh L, Karimi-Torshizi MA, Seidavi A, da Silva Araujo CS, Araujo LF. Feed supplementation with vermi-humus and earthworm (Eisenia foetida) powder on broiler productivity. Ital J Anim Sci 2021;20:1054-62. https:// doi.org/10.1080/1828051X.2021.1932615

117. Bahadori Z, Esmaielzadeh L, Karimi-Torshizi MA, et al. The effect of earthworm (Eisenia foetida) meal with vermihumus on growth performance, hematology, immunity, intestinal microbiota, carcass characteristics, and meat quality of broiler chickens. Livest Sci 2017;202:74-81. https://doi.org/ 10.1016/j.livsci.2017.05.010

118. Zang YT, Bing S, Zhang YZ, Sheng XW, Shu DQ. Effects of dietary supplementation with earthworm powder on produc- tion performance, blood characteristics, and heavy metal residues of broiler Pullets. J Appl Poult Res 2018;27:609-15. https://doi.org/10.3382/japr/pfy024

119. Nalunga A, Komakech AJ, Jjagwe J, Magala H, Lederer J. Growth characteristics and meat quality of broiler chickens fed earthworm meal from Eudrilus eugeniae as a protein source. Livest Sci 2021;245:104394. https://doi.org/10.1016/ j.livsci.2021.104394

120. Gholami H, Shargh MS, Zarabi M, Zerehdaran S. Effect of different levels of earthworm meal (Eisenia Fetida) on performance, carcass characteristics and blood parameters of broiler chickens. Anim Prod Res 2016;7:70-6.

121. Loh TC, Fong LY, Foo HL, Thanh NT, Sheikh-Omar AR. Utilisation of earthworm meal in partial replacement of soybean and fish meals in diets of broilers. J Appl Anim Res 2009;36:29-32.

122. Musa U, Yusur J, Haruna ES, Karsin PD, Ali UD. Termites as possible animal protein supplement for Japanese quail (Coturnix coturnix Japonica) chicks feed. Nigerian J Biotechnol 2004;15:48-51.

123. Pousga S, Sankara F, Coulibaly K, et al. Effects of replacement of fish meal by termites (Macrotermes sp.) on the weight evolution and the carcass characteristics of local poultry in Burkina Faso. Afr J Food Agric Nutr Dev 2019;19:14354-71.

124. Purwadari T, Ketaren PP, Sinurat AP, Sutikno I. Identification and evaluation of fiberhydrolytic enzymes in the extract of Termites (Glyptotermes montanus) for poultry feed application. Indonesian J Agric Sci 2003;4:40-7.

125. Babarinde SA, Oladunjoye IO, Ojebiyi OO, Oyedeji SA. Inclusion of honey bee slum gum in broiler chicken feed. Int J Agric Biol 2011;13:781-5.

126. Prakatur I, Miškulin I, Senčić Đ, et al. The influence of propolis and bee pollen on chicken meat quality. Vet Arhiv 2020;90:617-25. https://doi.org/10.24099/vet.arhiv.0888

127. Prakatur I, Miskulin M, Pavic M, et al. Intestinal morphology in broiler chickens supplemented with propolis and bee pollen. Animals 2019;9:301. https://doi.org/10.3390/ ani9060301

128. Haščík P, Trembecká L, Bobko $M$, Čuboň J, Kačániová $M$, Tkáčová J. Amino acid profile of broiler chickens meat fed diets supplemented with bee pollen and propolis. J Apic Res 2016;55:324-334. https://doi.org/10.1080/00218839.2016.12 45398

129. Kalafová A, Haščík P, Petruška P, et al. Effect of bee poolen in chicken diet on selected parameters of mineral profile. Acta Fytotechn Zootechn 2014;17:90-2. https://doi.org/10.15414/ afz.2014.17.03.90-92

130. Haščík P, Elimam I, Garlík J, et al. Impact of bee pollen as feed supplements on the body weight of broiler Ross 308 . Afr J Biotechnol 2012;11:15596-9.

131. Açıkgöz Z, Yücel B, Altan Ö. The effects of propolis supplementation on broiler performance and feed digestibility. Eur 
Poult Sci 2005;69:117-22.

132. Abdel-Kareem AAA, El-Sheikh TM. Impact of supplementing diets with propolis on productive performance, egg quality traits and some haematological variables of laying hens. J Anim Physiol Anim Nutr 2017;101:441-8. https:/doi.org/ 10.1111/jpn.12407

133. Rizk YS, Abuoghaba AA, Ismail II, Awadien NB. Egg production, egg quality traits and some hematological parameters of Sinai chicken strain treated with different levels of bee pollen. Egypt Poult Sci 2018;38:427-38. 